193УДК 159.923

doi: 10.15330/ps.10.1.186-192

Тетяна Титаренко

Інститут соціальної та політичної психології НАПН України, tetiana.tytarenko@ispp.org.ua

\title{
ПОСТТРАВМАТИЧНЕ ЖИТТЕТВОРЕННЯ ОСОБИСТОСТІ: МЕТОДИ ДІАГНОСТИКИ І ВІДНОВЛЕННЯ
}

\begin{abstract}
Представлено емпіричну верифікаџію наступних аспектів теорії відновлення психологічного здоров'я особистості: діапазону психологічних наслідків впливу травми на особистість; способів розподілу ресурсів особистості у складних умовах; засобів та прочедур визначення ефективності реабілітаційних впливів; перспектив забезпечення комплексної психосоціальної підтримки особистості. Апробовано комплекс методик, який використовувався колективом лабораторії соиіальної психології особистості при дослідженні посттравматичного етапу життетворення.

Показали свою ефективність наступні методи діагностики: методи опитування, глибинного та контекстуального інтерв 'ю, створення автонаративу. Інтерпретація результатів, отриманих в результаті використання якісних методів, здійснювалася за допомогою процедур контент-аналізу та аналізу творчих продуктів. Засвідчено інформативність методу інтерв 'ю, завдяки якому вдалося виявити вплив травматичних життєвих обставин на способи організації життєтворення, зміни стилю життя, апробацію нових копінгів.

Доведено формувально-відновлювальний вплив методів соціально-психологічної реабілітаџї на особистість. Здійснено перевірку ефективності реабілітаційних технологій з використанням методу феноменологічного аналізу індивідуальних та групових впливів та подальшим аналізом консультативних, психотерапевтичних $і$ тренінгових текстів, щзо дало змогу з'ясувати феноменологію травматичного досвіду постраждалих, зафіксувати наявність внутрішніх $i$ зовнішніх ресурсів для відновлення їхнього психологічного здоров'я та реконструювати иіннісно-смислові $і$ праксеологічні контексти посттравматичного життетворення.
\end{abstract}

Ключові слова: психологічне здоров'я, життєтворення особистості, воєнна травма, особистісні ресурси, психосоціальна підтримка, якісні діагностичні методи, методики реабілітації.

Постановка проблеми. Серед провідних показників особистісного життєтворення як найскладнішого виду людської творчості слід назвати готовність до креативного реагування на несподівані події [7]. На жаль, війна, яка триває вже чимало років, несе надмірну кількість випробувань, викликів, ризиків, що безумовно впливає на творче ставлення людини до власного життя. Внаслідок тривалої травматизації суттєво знижуються соціальноадаптивні можливості людей, втрачається колишній рівень особистісної цілісності, комунікативної компетентності, професійної самоефективності, психологічного благополуччя $[8 ; 9]$.

У ситуації хронічної невизначеності і небезпеки здатність особистості шукати нові способи поведінки, більш ефективні форми взаємодії з оточенням суттєво знижується. Готовність конструктивно проектувати власне майбутнє у тих, хто був травмований внаслідок виснажливих воєнних дій, внаслідок втрати близьких, вимушеного переселення в інші регіони, майже зникає. I тому набуває актуальності потреба розробки теоретико-методологічного та методичного базису для діагностики психологічних наслідків травмування та пошуку ефективних інтервенцій, спрямованих на їх подолання.

Мета дослідження - узагальнення методичних підходів колективу лабораторії соціальної психології особистості до комплексного вивчення впливу тривалої воєнної травматизації на процес життєтворення та визначення ефективних методів психологічної реабілітації постраждалих.

Аналіз останніх публікацій. При дослідженні психологічних наслідків воєнної травматизації найчастіше використовуються традиційні кількісні методи. Так, у південній Хорватії було проведене порівняльне дослідження 182 людей, що мали особистісні розлади внаслідок воєнних дій, та 86 людей, у яких відповідні розлади не діагностовано. Використовувалися метод експертних оцінок та Гарвардська травматологічна анкета. 
Встановлено, що у травмованої групи навіть через 15 років після закінчення війни набагато більше розповсюджені симптоми депресії, тривоги, ПТСР; вищий рівень міжособистісних дисфункцій; вищий рівень вживання алкоголю і психоактивних речовин [11].

Вивчення особливостей проживання особистістю посттравматичного періоду теж нерідко відбувається за допомогою кількісних методів. Так, у нещодавно проведеному дисертаційному дослідженні показали високий рівень надійності і валідності україномовні психодіагностичні методики для оцінювання рівня особистісного зростання учасників АТО («Опитувальник посттравматичного зростання» та «Опитувальник змін у поглядах») [2].

Водночас дослідження, пов'язані зі складними питаннями особистісних посттравматичних змін, з перспективами перебудови життєвого світу, з відповідальністю людини за самореалізацію, з побудовою нових траєкторій життєвого шляху зазвичай більше зорієнтовані на якісні методи. Надійність результатів, отриманих за допомогою якісного методу, залежить від якості інструментарію та характеристик самого процесу проведення інтерв'ю. Підвищення надійності такого якісного методу як, наприклад, напівструктуроване інтерв'ю, забезпечується насамперед структуруванням травматичного досвіду, конденсацією смислів, інтерпретацією власної ролі у пережитому $[1 ; 4 ; 6]$.

Феноменологічне напівструктуроване інтерв'ю вважається найпопулярнішим якісним методом, що передбачає бесіду, діалог між дослідником і досліджуваним. Інтерв'юер стає не дослідником-шахтарем, а дослідником-мандрівником, якщо скористатися постмодерністською метафорою С. Квале [4, с. 13-14]. В результаті він отримує якісні тексти, які дають змогу внаслідок структурованих інтерпретацій зануритися у життєвий світ досліджуваного, зрозуміти його цінності і смисли, передбачити певні поведінкові прояви.

Все більшої популярності набуває також якісний метод автобіографічного наративу, усного і письмового. Наведемо приклад з наративом Джошуа Манца, який отримав кулю снайпера під час виконання воєнної місії у Багдаді і пройшов складний шлях фізичного і психологічного відновлення, що і відтворив потім у власній книзі. Автор адресує свій текст не лише ветеранам, а й клініцистам, які шукають ефективні методи психологічної допомоги. Один із його висновків полягає в тому, що в період найбільшої емоційної вразливості, суїцидальних думок, глибокого відчаю людина найбільш відкрита для встановлення і поглиблення стосунків, які можуть допомогти їй знайти себе, свою мету, свій шлях із минулого у майбутнє. Крім книжки і розробки тренінгів, автор також працює із все більш популярним методом візуального наративу, розміщуючи на YouTube численні авторські відео, які надихають ветеранів [10].

Метод автобіографічного наративу використовується для подолання наслідків травматизації і в межах організаційної психології, наприклад, задля оптимізації статуснорольових, ділових, ціннісно-орієнтаційних, морально-етичних, здоров'язберігальних параметрів функціонування організаційних підрозділів і відновлення людей, що в них працюють [3].

Виклад основного матеріалу. В результаті специфікації поля соціально-психологічних впливів на травмовану війною особистість та використання методів теоретичного пізнання, системно-феноменологічного моделювання, концептуалізації та синтезу інтерпретативних моделей Т. М.Титаренко розроблено соціально-психологічну теорію відновлення психологічного здоров'я особистості [9]. Надалі перед науковим колективом лабораторії постало завдання емпіричної верифікації певних аспектів теорії, що потребувало розробки відповідного діагностичного та реабілітаційного інструментарію.

Центральною ланкою комплексного діагностичного інструментарію виявився метод сфокусованого індивідуального інтерв'ю, що передбачав безпосередній контакт людини, яка постраждала, і спеціаліста-психолога з усталеним фокусом на травматичній життєвій ситуації. Метод використовувався нашим колективом у різних формах: як вільна бесіда на задану тему без підготовленого плану і фіксованих запитань; як глибинне інтерв'ю на конфіденційну тему із заздалегідь продуманими питаннями; як наративне оповідання про пережите, що стимулюється глибокою зацікавленістю, «включеністю» слуха- 
ча. Йдеться як про перші ознайомлювальні бесіди, метою яких стає встановлення контакту, формування атмосфери довіри і взаєморозуміння, так і про більш глибокі і складні діагностичні діалоги, в яких досліджуються причини страхів комбатантів, що перебувають у зоні зіткнення; особливості формування стану відчуження у демобілізованих ветеранів; складнощі 3 реінтеграцією у суспільство, пошуком нових форм професійної самореалізації; зростання комунікативних проблем в сім'ї, на роботі тощо.

Кожний тип інтерв'ю залежно від його фокусу передбачав розробку відповідної схеми обробки отриманого матеріалу. Так, наприклад, первинне діагностичне інтерв'ю, що передувало консультативним, психотерапевтичним, реабілітаційним втручанням, для нашої вибірки включало такі показники:

$\checkmark$ актуальний стан, в якому перебуває травмована людина на момент звернення до спеціаліста (пригніченість, страхи, роздратованість, виснаженість, відстороненість тощо);

$\checkmark$ характер травмування, його особливості, тривалість, давність;

$\checkmark$ наявність попередніх травм, які були протягом життя, їх характер, наслідки;

$\checkmark$ індивідуальні способи подолання екстремальних ситуацій, які виникали раніше;

$\checkmark$ наявність чи відсутність мотивації до відновлення, ступінь готовності до змін у власному житті;

$\checkmark$ імовірність отримання підтримки сім’ї, друзів, близького оточення.

На основі глибинних інтерв'ю, проведених нашою співробітницею К. В. Мирончак 3 військовими, що на момент дослідження перебували у зоні бойових дій, виокремлено типи втрат військових, рівень їх прийняття, наявність внутрішніх та зовнішніх бар'єрів, що гальмують процес проживання втрати та знижують самоефективність військових. У результаті інтерв'ювання було побудовано трикомпонентну модель пошуку ресурсів відновлення [8, с. 152].

Поєднання методу глибинного інтерв'ю та автонаративу дало змогу молодому науковцю М. О. Чернявській дослідити таку складну проблему, як відчуження ветеранів від роботи, суспільства, значущих стосунків, від сім'ї та власного «Я» після повернення із зони бойових дій. Завдяки тандему двох якісних методів було виявлено низку причин відчуження, серед яких найголовніша - несправедливе ставлення до ветеранів з боку оточення, знецінення їхньої діяльності, бажань, намірів. Вдалося також провести диференційовану діагностику індивідуальної вираженості відчуження у різних формах та сферах життя учасників бойових дій [8, с. 170-171].

Ми використовували не лише інтерв'ю, які передбачали реальний безпосередній діалог з людиною, що постраждала. Проводилися також віртуальні діалоги з використанням все більш популярної сьогодні мережевої комунікації зі співрозмовником за допомогою Viber, Messendger та ін. У цьому випадку час між запитанням і відповіддю міг бути досить тривалим, від хвилин до годин і навіть днів. Акцент на вже знайомому, усвідомленому людиною, когнітивно-змістовому аспекті взаємодії майже без урахування мало усвідомлюваного емоційного аспекту з його нашаруваннями відчуження, образи, недовіри теж вносив свої корективи у взаєморозуміння співрозмовників і достовірність отримуваної інформації.

Апробувався і специфічний варіант діалогування, що отримав назву непрямого контекстуального інтерв'ю. Задля визначення загальноприйнятих індикаторів психологічно здорової особистості ми «інтерв'ювали» класиків психологічної науки, теорії яких $\epsilon$ загальновідомими і наводяться у підручниках, енциклопедіях, словниках. Для обробки даних використовувався метод контент-аналізу. Схожі висловлювання різних авторів об’єднувалися в інтегральні одиниці аналізу. Наступним кроком аналізу було визначення частотності кожного показника, побудова відповідної ієрархії індикаторів та їх групування. Так було виявлено найбільш розповсюджені індикатори психологічно здорової особистості, якими користується абсолютна більшість авторів. Відповідно, саме вони були визначені як ключові, тобто такі, на відновлення яких мають бути спрямовані зусилля психологів-реабілітологів. 
Кількісні методи, хоча і меншою мірою, все ж використовувалися нашим колективом. Так, для роботи з проблемною молоддю, що брала участь у воєнних діях, Б. П. Лазоренко сформував дослідницький комплекс з трьох опитувальників. Цей комплекс дав змогу визначити наявність посттравматичних стресових станів, прояви розладів адаптивності особистості та допомогти постраждалим людям адекватно оцінити ступінь реадаптації до сімейного і професійного післявоєнного життя [8, с. 71-73].

Особливу увагу наш науковий колектив звертав на активні методи, що мають формувально-відновлювальний вплив на травмовану війною особистість. Слід зауважити, що такі діагностичні методи, як глибинне інтерв'ювання, розповідь про пережите, написання автобіографічного наративу водночас сприяють переосмисленню власних переживань, новому тлумаченню травми і власної ролі в тому, що відбувалося. Наше дослідження показало, що якісні методики оптимізують перехід від діагностичного етапу інтерв'ювання до відновлювального етапу конструктивних змін у процесі особистісного життєтворення. У діалогічній взаємодії формуються нові цінності, виникають нові життєві орієнтації, оновлюється зміст взаємодії з оточенням, апробуються актуальні для посттравматичного життєтворення практики професійної, сімейної, особистої самореалізації.

Специфіка соціально-психологічної реабілітації полягає в ії спрямованості на активізацію життєтворення особистості, що постраждала внаслідок травмування. Реабілітація сприяє відновленню бажання самотрансформацій, здатності до проектування майбутнього та втілення цих проектів в різних сферах життєдіяльності.

Соціально-психологічними технологіями реабілітації ми вважаємо спрямовані на відповідні мішені комплексні впливи (техніки, інтервенції, процедури), що забезпечують збереження і відновлення особистісної цілісності, збалансованості, здатності до саморегуляції, самоефективності, комунікативної компетентності, активізації сенсопородження.

Індивідуальні і групові технології розгорталися одночасно у 4-векторній персонально-інструментально-просторово-часовій площині. Процес соціально-психологічного відновлення складався з підготовчого, базисного і підтримувального етапів. На підготовчому етапі показали свою ефективність технологія посилення мотивації щодо самозмін, технологія конструювання ефективних мотиваторів, технологія активізації сліпих зон уваги. На базисному етапі результативними виявилися технологія проектування майбутнього за допомогою життєвих виборів, технологія апробацій оновлених проектів за допомогою постановки життєвих завдань та технологія реалізації поставлених завдань за допомогою все більш успішного практикування. На підтримувальному етапі, який водночас виступає як профілактичний, використовувалися насамперед технологія переінтерпретації та інтеграції травматичних спогадів в загальний досвід особистості, технологія вироблення нового ставлення до травми як до ресурсу та технологія опосередкованого впливу на особистість через організацію більш екологічного середовища життєдіяльності.

Серед активних методів ми зосередилися на методі використання спільноти для покращення процесів життєтворчості. У дослідженні нашого співробітника В. О. Климчука цільове включення спільнот до підтримки психічного здоров'я особистості забезпечувалося через створення сприятливих умов та предикторів. Серед умов слід назвати активізацію різноманітної спрямованості спільнотної діяльності, підсилення готовності спільнот до надання підтримки своїм членам, поглиблення зв'язків спільнот між собою. Відповідно предикторами цільового включення особистості до спільнотного життя виявилися психологічна готовність особистості до отримання підтримки з боку певних спільнот (професійних, територіальних, екологічних, політичних тощо), стимулювання мотивації особистості до індивідуального внеску в життя спільнот, а особливо підвищення відповідальності особистості за діяльність спільнот, їх колективне самовизначення [8, с. 68-69].

У реабілітаційній роботі з внутрішньо переміщеними особами, яку проводила наша співробітниця Ю. Д. Гундертайло, широко використовувався метод клієнт-орієнтованої підтримки з боку спільноти. Метою такої підтримки було відновлення особистісної неперервності через посилення ролі спільноти, яка самостійно продовжувала конструктивну 
взаємодію після завершення основного циклу тренінгових занять. Спільнота забезпечувала формування нових соціальних зв'язків, стабілізацію емоційного стану учасників, розширення репертуару копінг-стратегій, що в цілому сприяло відновленню процесів посттравматичного життетворення [8, с. 180-181].

Ресурси спільноти були задіяні і в реабілітаційній роботі з проблемною молоддю. Б. П. Лазоренко ініціював створення груп самодопомоги, лідерами яких ставали ветерани. Посттравматичне життєтворення схильної до ризикованої поведінки молоді відбувалося більш успішно завдяки позитивному досвіду активних членів спільноти, яким вдалося знайти своє місце у соціумі, покращити професійний статус, налагодити стосунки в сім'ї, позбутися шкідливих звичок [8, с. 93-94].

Продуктивний варіант залучення спільноти до реабілітації апробувався К. В. Мирончак у роботі з військовими, що пережили втрату. Йдеться про широко розповсюджені практики взаємодії та підтримки, які покращували самоефективність особистості як важливий компонент відновлюваної життєтворчості. Результати дослідження свідчать, що особливо впливає підтримка тих друзів і рідних, які поділяють цінності військовослужбовця, поважають його вибір, вірять у можливості відновлення. Також дуже важливою виявилася налагоджена взаємодія 3 побратимами, оскільки внутрішньогруповий процес злиття через зміцнення поняття «ми», відчуття належності запускає важливі зміни у самоідентифікації оновлюваної після втрат особистості [8, с. 150].

Наявність досить великих груп людей, що внаслідок отримання воєнних травм потребують реабілітаційних впливів, підштовхнула нашого співробітника В. В. Савінова до апробації такого методу активізації життєтворення, як участь у виставі плейбек-театру в якості оповідача, глядача, актора. Було доведено, що під час вистави відбувається не лише індивідуальне відновлення наратора, який готовий поділитися своєю травматичною історією, а й відновлення групове. Встановлено основні відновлювальні ефекти для особистості, яка представляє автонаратив, публічно розповідаючи власну історію під час плейбек-театрального дійства: 1) знаходження нових зв'язків між складниками травматичної історії, тобто часткова переінтерпретація ситуації із самостійним виявленням прихованих ресурсів; 2) відчуття підтримки з боку інших людей завдяки переживанню, що тебе почули, зрозуміли, поділили твої емоції; 3) наявність катарсичного ефекту, коли актори виражають почуття людини, які вона не в змозі виразити самостійно; 4) ефект відстороненості, «неучасті» [8, с. 188].

Певна частина активних методів, що сприяли посттравматичному життєтворенню, була спрямована на відновлювальні ресурси особистості: інструментальні і базові.

Інструментальні ресурси широко розповсюджених мобільних застосунків, які легко встановити на власних смартфонах і планшетах, за даними М. С. Дворник, сприяють структуризації корисної для особистості інформації щодо травматичних станів та переживань, самостійній оцінці власних симптомів, використанню засобів реабілітаційного комунікування та моніторингу змін, частковому заміщенню процедур професійного супроводу реабілітаційного процесу [8, с. 138-139].

Медійні технології як інструментальні ресурси залучала у свою реабілітаційну роботу також К. В. Мирончак. Зростання запиту на такі медійні проекти, як «Герої не вмирають», «Будемо жити!» 3 поступовою, опосередкованою стимуляцією внутрішньої активності людини свідчить про їхню продуктивність для відновлення самоефективності особистості, що пережила втрату [8, с. 158].

Методи підживлення базових ресурсів особистості були в центрі уваги Т. О. Ларіної. Побудована нею модель ресурсів особистості включала копінг-стратегії, практики керування ризиками, способи діалогічного спілкування та соціальної підтримки. Продуктивним виявився метод відновлення життєздатності особистості, що складався 3 технік підвищення рівня довіри, коригування негативних комунікаційних настановлень, безпекових навичок тощо [8, с. 104-109]. 
Тексти, отримані авторами під час проведення індивідуальних консультацій, психотерапевтичних сесій, тренінгової взаємодії, аналізувалися за допомогою методу індивідуального екзистенційного аналізу А. Ленгле [5] та методу інтерпретативного феноменологічного аналізу Дж. Смитса, М. Осборна [12]. Поєднання цих методів дало змогу побачити конструктивну динаміку в особистісному пошуку нових сенсів, побудові життєвих перспектив, покращенні взаємодії з оточенням.

Висновки. Комплекс методик, який використовувався колективом лабораторії соціальної психології особистості при дослідженні посттравматичного етапу життєтворення, забезпечив емпіричну верифікацію таких аспектів теорії відновлення психологічного здоров'я особистості: діапазону психологічних наслідків впливу травми на особистість; способів розподілу ресурсів особистості у складних умовах; засобів та процедур визначення ефективності реабілітаційних впливів; перспектив забезпечення комплексної психосоціальної підтримки особистості.

Показали свою ефективність наступні методи діагностики: методи опитування, глибинного та контекстуального інтерв'ю, створення автонаративу. Інтерпретація результатів, отриманих в результаті використання якісних методів, здійснювалася за допомогою процедур контент-аналізу та аналізу творчих продуктів.

Найбільш інформативним виявився метод інтерв'ю, який дав змогу виявити вплив реальних життєвих обставин, в яких опинилися постраждалі внаслідок певних катаклізмів люди, на способи організації життєтворення, зміни стилю життя, апробацію нових копінгів.

Використання активних методів, які отримали назву технологій соціально-психологічної реабілітації, засвідчило їх формувально-відновлювальний вплив на особистість, що пережила травму.

Перевірка ефективності реабілітаційних технологій здійснювалася завдяки методу феноменологічного аналізу індивідуальних та групових впливів 3 подальшим аналізом консультативних, психотерапевтичних і тренінгових текстів через реконструкцію ціннісно-смислового та праксеологічного контекстів. Використання цих методів дало змогу не лише з'ясувати феноменологію травматичного досвіду постраждалих, зафіксувати наявність внутрішніх і зовнішніх ресурсів для відновлення їхнього психологічного здоров 'я, а й побачити перспективи посттравматичного життєтворення.

1. Байєр, О. О. (2019). Якісні методи дослідження взаємозв'язку рис та підструктур особистості. Роль рівня сформованості диспозииійних та динамічних властивостей особистості у зумовленні якості життя: монографія. Дніпро: Ліра,76-103.

2. Зубовський, Д. С. (2019). Особистісне зростання учасників АТО у посттравматичний період (Дис. канд. психол. наук). Національний університет оборони України імені ІванаЧерняховського, Київ.

3. Карпенко, 3. С. (2018). 3 досвіду застосування автобіографічного наративу в організаційній психології: аксіологічна оптика. Психологія особистості, 1 (9), 96-104.

4. Квале, С. (2003). Исследовательское интервью. Москва: Смысл.

5. Лэнгле А. (2009). Персональный экзистенциальный анализ. Психология индивидуальности: Новые модели и конщепиии. Старовойтенко Е. Б., Шадрикова В. Д. (Ред.). Москва: НОУ ВПО МПСИ, 356-382.

6. Методы соииальной психологии в психологическом консультировании (2012). Н. С. Минаева (Ред.). Екатеринбург: Изд-во Уральского университета.

7. Психологія життєтворення особистості у сучасному світі (2016). Т. М. Титаренко (Ред.). Київ: Міленіум.

8. Соціально-психологічні технологї відновлення особистості після травматичних подій (2019). Т. М. Титаренко (Ред.). Кропивницький: Імекс-ЛТД.

9. Титаренко, Т. М. (2018). Психологічне здоров'я особистості: засоби самодопомоги в умовах тривалої травматизаиії. Кропивницький: Імекс-ЛТД.

10. Lira, L. L. (2019). The Beauty of a Darker Soul: Overcoming Trauma Through the Power of Human Connection. Journal of Veterans Studies, 4 (2).

11. Munjiza, J. , Britvic, D., Radman, M., Crawford, M. (2017). Severe war-related trauma and personality pathology: a case-control study. BMC Psychiatry, 17:100. DOI 10.1186/s12888-017-1269-3.

12. Smith, J. A., \& Osborn, M. (2015). Interpretative phenomenological analysis as a useful methodology for research on the lived experience of pain. British Journal of Pain, 9 (1), 41-42. https://doi.org/10.1177/ 2049463714541642 . 
1. Baiier, O. O. Yakisni metody doslidzhennia vzaiemozviazku rys ta pidstruktur osobystosti. Rol rivnia sformovanosti dyspozytsiinykh ta dynamichnykh vlastyvostei osobystosti u zumovlenni yakosti zhyttia : monohrafia [The role of the level of formation of dispositional and dynamic personality traits in determining the quality of life: a monograph.], 76-103. (ukr.).

2. Zubovskyi, D. S. (2019). Osobystisne zrostannia uchasnykiv ATO u posttravmatychnyi period [Personal growth of participants in the antiterrorist operation in the post-traumatic period]. (Dissertation for a candidate of psychological sciences). Dissertation for a candidate of psychological sciences degree in specialty, Kyiv. (ukr.).

3. Karpenko, Z. S. (2018). Z dosvidu zastosuvannia avtobiohrafichnoho naratyvu v orhanizatsiinii psykholohii: aksiolohichna optyka [From the experience of autobiographical narrative application in organizational psychology: axiological optics]. Psykholohiia osobystosti [Psychology of personality], 1 (9), 96-104. (ukr.).

4. Kvale, S. (2003). Issledovatelskoye intervyu [Research interview]. Moskov: Smysl. (rus.).

5. Lengle, A. (2009). Personalnyy ekzistentsialnyy analiz [Personal existential analysis]. Psihologija individual'nosti. Novye modeli i konzepcii [Psychology of personality: New models and concepts]. Starovoitenko E. B., Schadrikova W. D. (Ed.). Moskva: NOU VPO Moskovskij psihologo-sozialnyj institut, 356-382. (rus.).

6. Metody sotsialnoy psikhologii v psikhologicheskom konsultirovanii [Methods of social psychology in psychological counseling] (2012). N. S.Minayeva (Ed.). Ekaterinburg: Izd-vo Uralskogo universiteta. (rus.).

7. Psykholohiia zhyttietvorennia osobystosti u suchasnomu sviti [Psychology of personality formation in the modern world] (2016). T. M. Tytarenko (Ed.), Kyiv: Milenium. (ukr.).

8. Sotsialno-psykholohichni tekhnolohii vidnovlennia osobystosti pislia travmatychnykh podii [Socio-psychological technologies of personality recovery after traumatic events] (2019). T. M.Tytarenko (Ed.). Kropyvnytskyi: Imeks-LTD. (ukr.).

9. Tytarenko, T. M. (2018). Psykholohichne zdorovia osobystosti: zasoby samodopomohy v umovakh tryvaloi travmatyzatsii [Psychological health of the individual: self-help in the conditions of prolonged traumatization.]. Kropyvnytskyi: Imeks-LTD. (ukr.).

10. Lira, L. L. (2019). The Beauty of a Darker Soul: Overcoming Trauma Through the Power of Human. Journal of Veterans Studies, 4 (2).

11. Munjiza, J. , Britvic, D., Radman, M., Crawford, M. (2017). Severe war-related trauma and personality pathology: a case-control study. BMC Psychiatry, 17:100 // DOI 10.1186/s12888-017-1269-3.

12. Smith, J. A., \& Osborn, M. (2015). Interpretative phenomenological analysis as a useful methodology for research on the lived experience of pain. British Journal of Pain, 9 (1), 41-42. https://doi.org/10.1177 /2049463714541642.

\section{Tetiana Tytarenko \\ PERSONALITY POST-TRAUMATIC LIFE-DESIGNING: DIAGNOSTICS AND RESTORATION METHODS}

The empirical verification of the following aspects of the psychological health restoration theory is presented: the range of psychological consequences of the trauma impact on the personality; ways of allocating resources of the personality in difficult conditions; the means and procedures for determining the effectiveness of rehabilitation impacts; prospects of providing comprehensive psychosocial support for the personality. The complex of methods that were used by the staff of the laboratory of the social psychology of personality in the study of the post-traumatic stage of life formation was tested.

The following diagnostic methods have been effective: interviewing methods, in-depth and contextual interviews, and creating self-narratives. Obtained through the use of qualitative methods the interpretation of the results was carried out using the procedures of content analysis and analysis of creative products. The informative method of interviewing, through which we were able to identify the impact of traumatic life circumstances on the ways of life organization, lifestyle changes, testing of new copings, is attested.

The formative-restorative influence of social-psychological rehabilitation methods on the individual is proved. The effectiveness of rehabilitation technologies was tested using the method of phenomenological analysis of individual and group influences and the subsequent analysis of counseling, psychotherapeutic and training texts, which made it possible to find out the phenomenology of traumatic experience of the victims, to fix the presence of internal and external resources for psychological health restoration and reconstruct value-meaning and praxeological contexts of post-traumatic life.

Keywords: psychological health, personality constraction, war trauma, personal resources, psychosocial support, qualitative diagnostic methods, rehabilitation techniques. 